\title{
SOME ASPECTS OF THE POLLEN MORPHOLOGY OF THE GENUS SANGUISORBA L. (ROSACEAE)
}

\author{
TJ. REITSMA \\ Botanical Museum and Herbarium, State University, Utrecht (The Netherlands) \\ (Received November 11, 1966)
}

SUMMARY

Eight species of the genus Sanguisorba $L$. were studied. Two distinct types could be recognized, viz., the Sanguisorba minor and the Sanguisorba officinalis type. Sanguisorba filiformis (HoOKER fil.) HANDELL-MAzZETTI appeared to be a transition between these two types.

\section{INTRODUCTION}

In the genus Sanguisorba L. two different types of pollen grains have been recognized. Sanguisorba minor is considered 3-colporate (FAEGRI and IVERSEN, 1950; ERdTMAN et al., 1961). In contrast Sanguisorba officinalis usually has been described as 6-colporate. Sometimes, however, 3-colporate pollen grains are found in Sanguisorba officinalis, specially in diploid specimens (ERDTMAN and NORDBORG, 1961; ERDTMAN et al., 1961). They, however, do not give any information on the difference between the pollen grains of diploid and tetraploid plants of Sanguisorba officinalis. Yet the difference seems to be important since they write (ERDTMAN and NordBorg, 1961, p.19): "Mit Hinsicht auf die Grösse und auf die feinmorphologischen Einzelheiten sind die Pollenkörner so verschieden, dass sie unschwer für eine indirekte Bestimmung der Chromosomenzahl verwendet werden können".

Up to now, 6-colporate pollen grains in the Rosaceae have been found only in Sanguisorba officinalis L. Yet this species does not show striking differences in other taxonomic characters that would set it apart from the family or even the genus Sanguisorba (it even is the type for the genus).

On theoretical grounds, the present author (REITSMA, 1966) prefers 3-colporate above 6-colporate. Pollen grains usually have a symmetrical ground plan. When the number of apertures is even then they are situated opposite to each other (e.g., in pollen grains of Galium). This is not true in the 6-colporate pollen 
grains of Sanguisorba officinalis type (Plate IG,H; Plate IIA,B). (Hence it seems to be more reasonable to accept an odd number of apertures, in this case 3.)

In the present study, some additional species of the genus Sanguisorba $\mathbf{L}$. are considered in the hope to obtain more pollen-morphological evidence in support of the theory that all species of Sanguisorba L. have pollen grains that are basically 3-colporate.

MATERIAL

The species studied are: Sanguisorba canadensis L., S. filiformis (Hooker fil.) Handell-Mazzetti, $S$. magnolii (Spach) Roth et Silva, S. microcephala Prest, S. minor SCOPOl, S. officinalis L., S. rhodopaea HAYEK, S. spinosa BerTOLINI, S. tenuifolia FISCHER.

METHODS

The pollen grains were treated with the acetolysis method of ERDTMAN (1943) and embedded in glyecrine jelly. The microphotographs were made with a Leitz Orthomat camera and Ortholux microscope, obj. apochrom. $\times 40, \times 63$, pl. apo öl $100 / 1.32$ and an eyepiece $\times 10$.

\section{DESCRIPTION}

The diagnosis of the Sanguisorba type and the two subtypes are these:

Sanguisorba type (RerTsma, 1966): Tricolporate; fastigiate; psilate; infrastriate; operculate; C.I. $<3$; suboblate-prolate; equatorial vicw: oval-rhomboidal; polar view: circular.

\section{PLATE I}

A,B. Singuisorba minor. A. Equatorial view, $\times 900$. B. Polar view, optical section, $\times 1700$.

C-F. S. afficinalis. C. Equatorial view, tetraploid form, $\times 1700$. D. Polar view, optical section, tctraploid form, $\times 1700$. E. Polar view, diploid form, $\times 1700$. F. Polar view, tetraploid form, $\times 900$.

G,H. S. canadensis. G. Equatorial view, upper site, $\times 2000$. H. Equatorial view, optical section, $\times 2000$. 


\section{PLATE I}
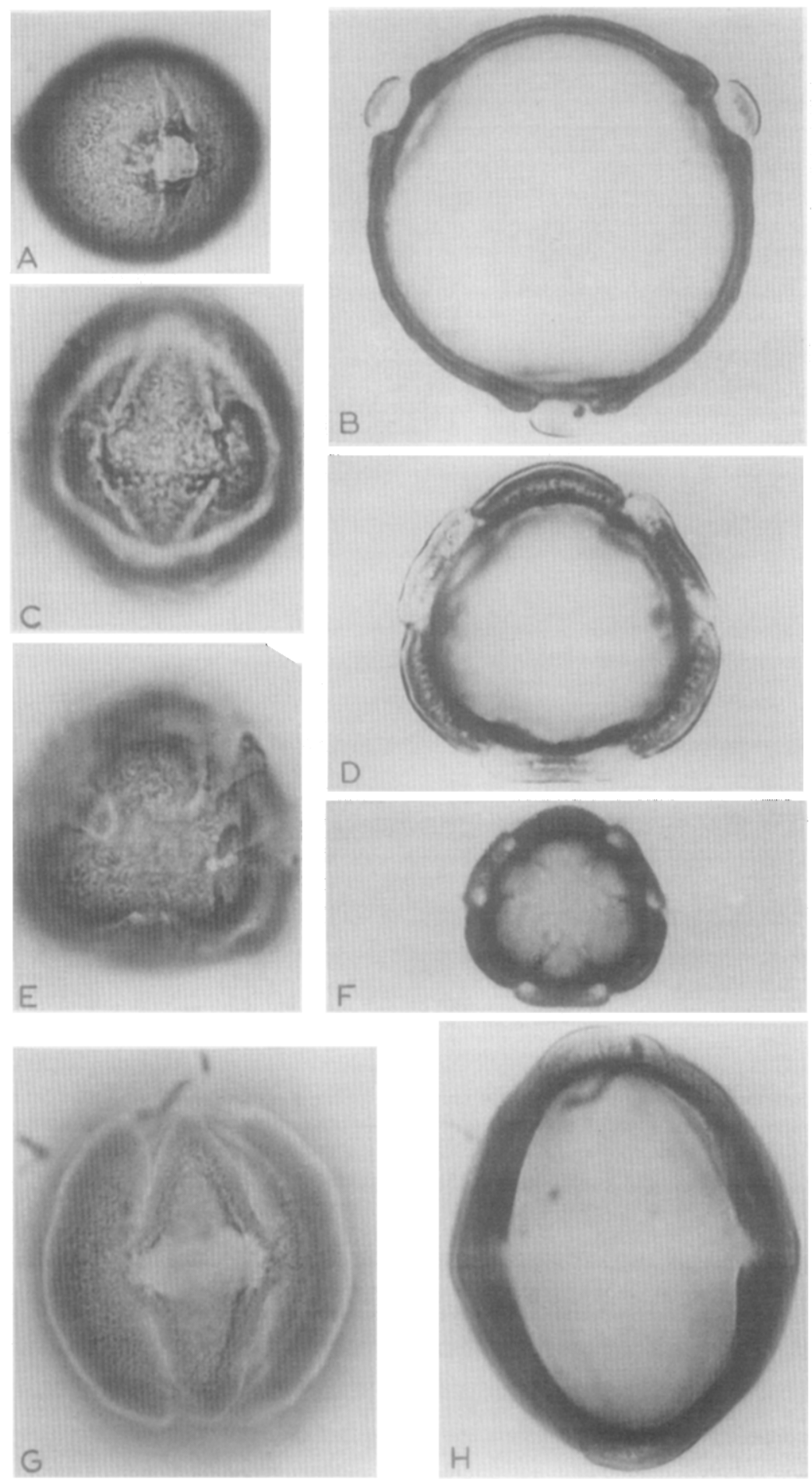
PLATE II
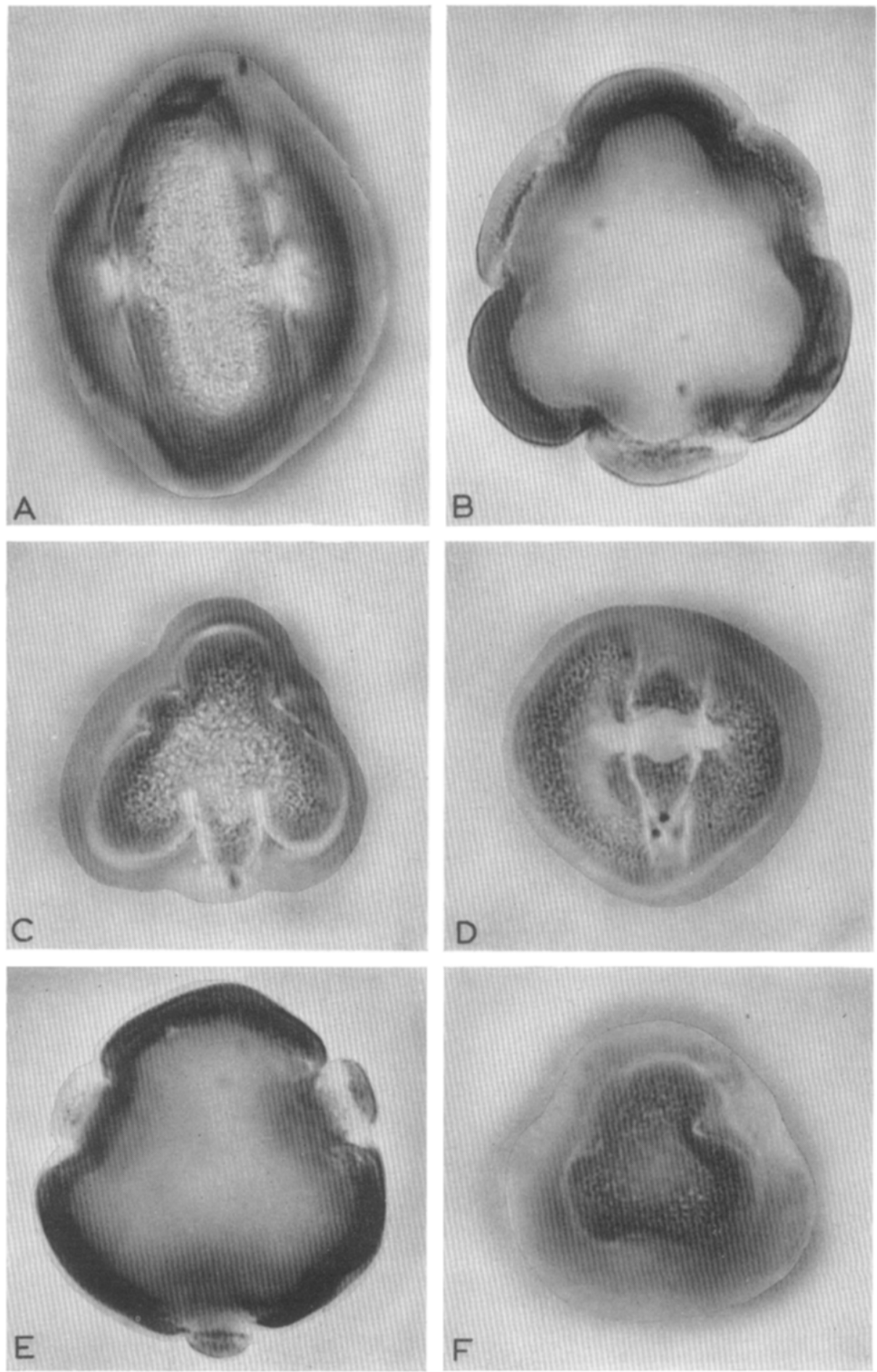
S. minor subtype (Reitsma, 1966) (Plate IA): Maximum width of the colpus $<$ maximum width of the mesocolpium; operculum protruding from the fastigium; end of the colpus distinct.

Species studied:

S. magnolii (SPACH) Roth et Silva; Fontes, Myre, Rainha et Silva, 1476$1946 / \mathrm{U} /$.

Diagnosis: P:E 0.85-0.96, P.A.I. 0.3-0.4, longest axis 35-46 $\mu$.

$S$. minor Scopoli; Leg. Stud. Biol. in it. Youg. 392-1960/U/, Herb. Behrendsen $19 / \mathrm{U} /$.

Diagnosis: P:E 0.8-0.97, P.A.I. 0.3-0.4, longest axis 29-35 $\mu$

S. rhodopaea HAYEK; Cantonspark 479-1932/U/.

Diagnosis: P:E 0.88-1.02, P.A.I. 0.3-0.4, longest axis 35-40 $\mu$.

S. spinosa BerTOLINI; Amdursky s.n. 1931 /U/.

Diagnosis: P:E 0.85-0.98, P.A.I. 0.3-0.6, longest axis $30-36 \mu$.

S. officinalis subtype (REITSMA, 1966) (Plate IB): Maximum width of the colpus approximately the maximum width of the mesocolpium; operculum not protruding from the fastigium; ends of the colpus most indistinct.

Species studied:

S. canadensis L.; Ten Houten et Schoenmakers 403-1935/U/. Diagnosis: P:E 1.25-1.40, P.A.I. 0.15-0.25, longest axis 35-40 $\mu$.

S. filiformis (HOOKER fil.) HANDELL-MAZZETTI; Young husband s.n. 1903/U/. Diagnosis: P:E 0.95-1.1, P.A.I. 0.15-0.25, longest axis 26-32 $\mu$.

S. microcephala PresL; F. W. Went, $117 / \mathrm{U} /$.

Diagnosis: P:E 1.35-1.55, P.A.I. 0.15-0.25, longest axis 34-43 $\mu$.

S. officinalis L.; Van Mourik s.n. 1962 /U/, Hekking s.n. 1964 /U/, Stud. Biol. in it. Norv. 367-1956/U/.

Diagnosis: P:E 1.04-1.32, P.A.I. 0.15-0.25, longest axis 26-39 $\mu$.

$S$. tenuifolia FisCHER; Kitamura et Murata 2294-1964/U/.

Diagnosis: P:E 1.3-1.7, P.A.I. 0.15-0.20, longest axis 35-40 $\mu$.

DISCUSSION

The size of the pollen grains of $S$. officinalis varies. Either the maximum

PLATE II

A-C. Sanguisorba canadensis. A. Equatorial view, lower site, $\times 2000$. B. Polar view, optical section, $\times 2000$. C. Polar view, $\times 2000$.

D-F. S. filiformis. D. Equatorial view, $\times 2000$. E. Polar view, optical section, $\times 2000$. F. Polar view, $\times 2000$. 
length is $26-32 \mu$ or it is $33-39 \mu$. This corresponds with the results of ERdTMAN et al. (1961) for diploid and tetraploid plants. The ends of the colpus may be distinct in diploid forms, but they are indistinct in tetraploid forms (Plate ID-F). Other differences in the pollen grains of diploid and tetraploid plants have not been found.

Among the species studied by the present author, $S$. canadensis and $S$. fliformis appeared to be important in connection to the problem of 6-colporate or 3-colporate. S. canadensis might be considered 6-colporate but the limitation of the operculum in the colpus and the mesocolpia, so striking in the S. minor subtype, is also distinct here (Plates I and IIA-C).

No one would be inclined to describe the pollen grains of $S$. filiformis as 6-colporate, but the mesocolpium and the operculum are of about the same size and the operculum does not protrude from the fastigium (Plate IID-F). These are characters only found in the $S$. officinalis subtype. Thus the pollen grains of $S$. filiformis form a transition between these two subtypes.

The conclusion can now be justified that what was originally described as the colpus is the nexine membrane between the edge of the colpus and the large operculum. Thus, this group of pollen grains is not 6-colporate, but 3-colporate.

\section{NOTE ADDED IN PROOF}

The important paper of NordBorg (1966) on the genus Sanguisorba and its allies only became available to the present author after completion of his manuscript.

\section{REFERENCES}

Erdtman, G., 1943. An Introduction to Pollen Analysis. Chronica Botanica Co., Waltham, Mass./ Almqvist and Wicksell, Stockholm, 239 pp.

Erdtman, G., Berglund, B. and Praglowski, J., 1961. An introduction to a Scandinavian pollen flora. Grana Palynologica, 2: 3-92.

Erdtman, G. und Nordborg, G., 1961. Über Möglichkeiten die Geschichte verschiedener Chromosomenzahlenrassen von Sanguisorba officinalis und Sanguisorba minor pollenanalytisch zu beleuchten. Botan. Notiser, 114: 19-21.

FAEGri, K. and IVERSEN, J., 1950. Textbook of Pollen Analysis. Munksgaard, Copenhagen, $168 \mathrm{pp}$. Nordborg, G., 1966. Sanguisorba L., Sarcopoterium SPACH, and Bencomia WebB et Berth. Delimitation and subdivision of the genera. Opera Botanica, 11: 2 (Dec. 14, 1966).

Reitsma, Tu., 1966. Pollen morphology of some European Rosaceae. Acta Botan. Neerl., 15: 290-307. 